\title{
Estudantes levaram 0 povo para a rua
}

Luiz Otávio Ribas ${ }^{1}$

Estudantes erguem uma bandeira

Um diretório livre, um território livre

Bolitas para as patas dos cavalos

Uma mão espalmada cobre o rosto do anonimato

Estudantes ocupam um prédio

Dois pés sobre a mesa do Reitor

Um restaurante, uma casa, uma sala de aula

Tudo feito pelos estudantes

Ombro a ombro do fundo de campo ao centro da cidade

Uma universidade pintada com a cara, a cor e o jeito do povo

Levaram o povo para a rua

Ela é sua

pra baixar a passagem

pelo passe livre

pra mudar o país

Rio de Janeiro, junho de 2013

1 Doutorando em Filosofia e Teoria do Direito na Universidade Estadual do Rio de Janeiro e pesquisador do IPDMS. 